\title{
Immunity and its role in periodontal diseases
}

\author{
Imunitatea şi rolul său în afecţiunile parodontale
}

\begin{tabular}{c} 
Irina Dumitrache \\
Product Manager Prisum-Himalaya \\
\hline
\end{tabular}

\begin{abstract}
Periodontal disease is one of the most common chronic disese, with a prevalence between $5 \%$ and $30 \%$ in adult population aged $25-75$.

In the pathogenesis of periodontal disease, the host immune response has a great importance and in the last years it has been underlined the role of immunomodulatory therapy in the management of periodontal disease. Septilin is a herbal immunomodulatory with clinical efficacy proven in the periodontal disease.

Keywords: periodontal disease, Septilin, immunomodulatory therapy, herbal product, Himalaya

REZUMAT

Boala parodontală este una dintre cele mai comune afecţiuni cronice, cu o prevalenţă între 5 şi $30 \%$ în populaţia adultă cu vârsta cuprinsă între 25 şi 75 de ani.

În patogeneza bolii parodontale, răspunsul imun al gazdei are o mare importanţă, iar în ultimii ani a fost subliniat rolul terapiei imunomodulatoare în controlul bolii parodontale. Septilin este un imunomodulator natural, cu eficienţa dovedită clinic în boala parodontală.

Cuvinte cheie: afecţiuni parodontale, Septilin, terapie imunomodulatoare, produs natural,
\end{abstract} Himalaya

Informații despre afecțiunile parodontale au fost descoperite încă din timpuri străvechi. Una dintre cele mai vechi dovezi în acest sens o reprezintă papirusul egiptean Ebers, care face referire la anumite remedii utile pentru ,dinții mobili şi gingiile umflate“. O primă clasificare a acestei afecțiuni a fost realizată de către un important medic din India antică, pe nume Sushruta (sec. 6 î.e.n), care a descris în tratatul său, Suśruta-samhitā, patru afecțiuni parodontale (1).

Boala parodontală se prezintă sub aspecte diferite, cu o arie variată de manifestare, progresând de la afectarea țesuturilor gingivale până la distrucția parodonțiului.

Actualmente, boala parodontală se numără printre cele mai comune afecțiuni cronice, având o prevalență între 5 şi $30 \%$ în populația adultă cu vârsta cuprinsă între 25 şi 75 de ani. Această prevalență ridicată poate fi explicată prin faptul că asupra complexului dento-alveolar acționează în mod continuu diverşi factori, încă din momentul apariției dentiției pe arcadele dentare. Printre aceşti factori se regăsesc alimentația dezechilibrată, cantitatea fluxului salivar, statusul imun, anumite medicamente, dar şi dezechilibrul bacteriilor cantonate la nivelul cavității bucale.

Biofilmele dentare includ o importantă diversitate a speciilor bacteriene. Cercetări recente efectuate în domeniul biologiei moleculare asupra microflorei din cavitatea orală au dus la identificarea a circa 700 de specii bacteriene (2). Este cunoscut faptul că între speciile componente ale microflorei de la acest nivel există un echilibru dinamic. Biofilmul are o funcție ,cheie“ în dezvoltarea fiziologică a gazdei, fiind important în prevenirea colonizării organismului de către microorganisme patogene exogene. Este unanim acceptat că una din primele linii de apărare parodontală este oferită de granulocite şi neutrofile. Sistemul imunitar al unei persoane sănătoase este într-o stare de simbioză cu biofilmul, beneficiile fiind mutale (3). 


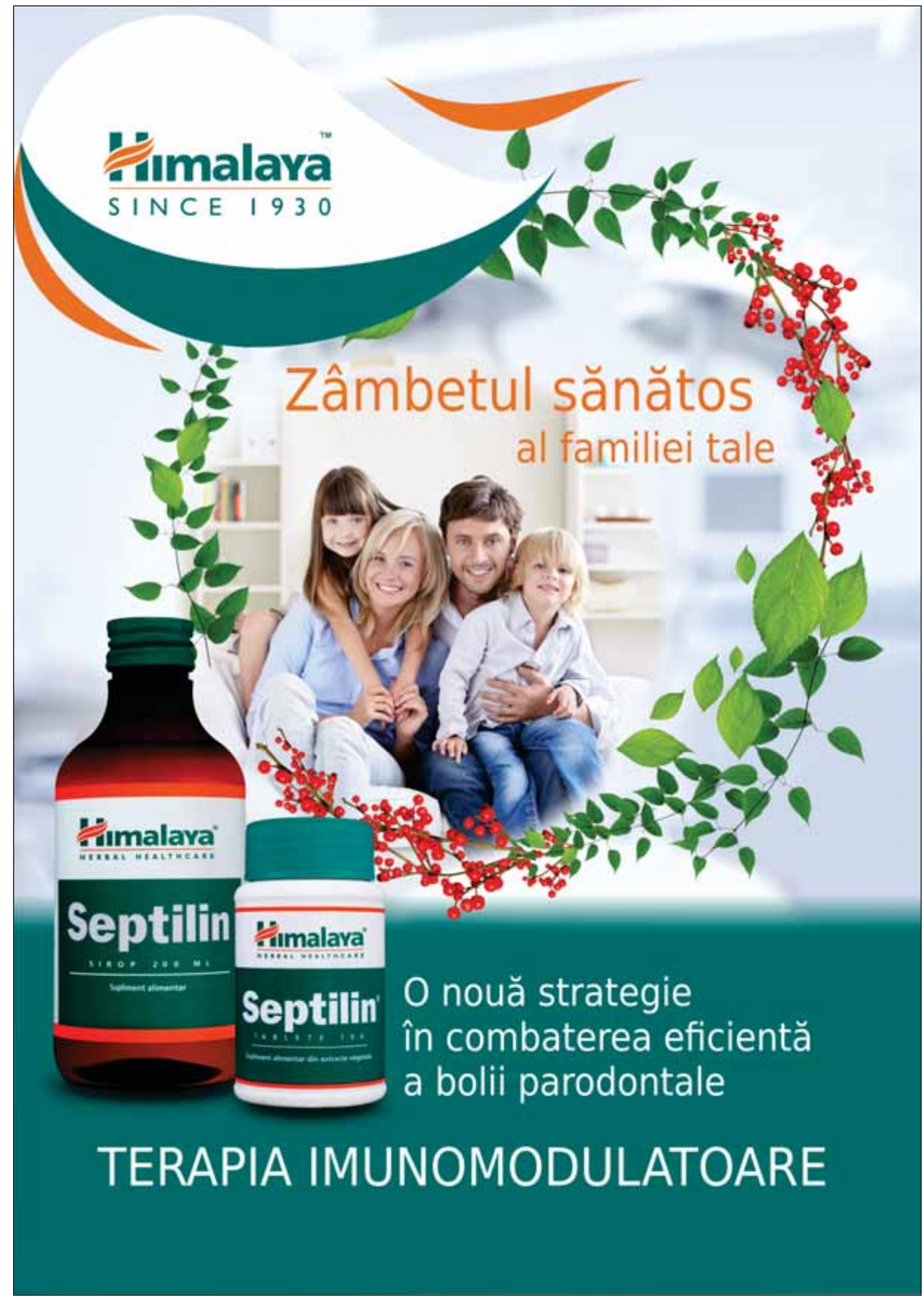

În anumite situații se ajunge la exacerbarea răspunsului imun al gazdei, ceea ce duce la intensificarea producerii de citokine proinflamatorii şi activarea metaloproteinazelor, având drept consecință distrucția țesuturilor de susținere ale dinților.
Cum venim în ajutorul sistemului imunitar?

Susținerea de care avem nevoie pentru sistemul nostru imunitar vine din inima naturii. Actualmente, compania Himalaya este un lider în domeniul 
fitoterapiei bazată pe dovezi ştiințifice, în toate cele 92 de țări unde se regăsesc produsele din portofoliul său.

\section{Septilin - imunomodulator eficient cu ingrediente $100 \%$ naturale!}

Septilin este un imunomodulator natural, care are rolul de a crește imunitatea nespecifică a organismului şi de a reduce reacțiile inflamatorii şi alergice. Este util în toate procesele infecțioase bacteriene sau virale, precum şi ca adjuvant în alergii.

Ce plante are în compoziţie?

Balsamodendron mukul are proprietăți imunomodulatoare, creşte capacitatea de fagocitoză a leucocitelor şi stimulează eliberarea lor în circulație şi are efect antiinflamator.

Glicirizina din planta Glicirrhiza glabra este responsabilă pentru scăderea interleukinelor, a $\operatorname{IgE}$ şi a TNF $\alpha$, stimulează producţia de interferon şi sinteza de $\operatorname{IgM}, \operatorname{IgA}$ şi IgG. O altă plantă recunoscută ca fiind eficientă în combaterea afecțiunilor parodontale este Rubia cordifolia. Printre substanțele active ale sale cu acțiune imunomodulatoare se numără coriofoliosidele şi syringinul.

\section{Cum acționează Septilin în boala parodontală?}

Printre beneficiile produsului Septilin în boala parodontală se numără reducerea inflamației gingiei, a indexului gingival de sângerare (GBI) şi a dimensiunilor pungii paradontale (PD). De asemenea, în urma studiilor realizate, a fost demonstrat faptul că Septilin îmbunătățeşte indexul gingival (GI) şi că scade citokinele proinflamatorii în salivă şi lichidul crevicular (GCF).

Aşadar, o cură cu Septilin, în dozele recomandate şi pe o perioadă de timp suficientă, este aliatul de nădejde al sistemului imunitar al pacienților cu afecțiuni parodontale.

\section{STUDII CLINICE}

Septilin determină îmbunătățirea semnelor clinice şi scăderea IL-6 din salivă şi GCF (4).

În acest studiu au fost urmăriți 96 de pacienți cu parodontită cronică cărora le-a fost propusă o terapie imunomodulatoare cu produsul Septilin.
O parte dintre pacienți au primit 2 tablete de Septilin, de două ori pe zi, timp de 2 săptămâni şi au prezentat rezultate mai bune comparativ cu lotul control.

În concluzie, terapia cu imunomodulatoare se dovedeşte a fi utilă în tratarea pacienților cu parodontită cronică.

\begin{tabular}{|c|c|c|c|c|c|c|}
\hline $\begin{array}{c}\text { Perioadă } \\
\text { evaluare }\end{array}$ & Grup & GI & GBI & PD & IL 6 - Sal & IL6 - GCF \\
\hline \multirow{2}{*}{ Iniţial } & Sep lin & 1.919 & 0.95 & 7.584 & 0.222 & 0.229 \\
\cline { 2 - 7 } & Control & 2.059 & 0.98 & 7.34 & 0.222 & 0.222 \\
\hline \multirow{2}{*}{ 1 lună } & Sep lin & 1.716 & 0.73 & 3.247 & 0.186 & 0.208 \\
\cline { 2 - 7 } & Control & 1.895 & 0.86 & 5.929 & 0.211 & 0.215 \\
\hline \multirow{2}{*}{ 3 luni } & Sep lin & 1.691 & 0.72 & 2.937 & 0.179 & 0.202 \\
\cline { 2 - 7 } & Control & 1.895 & 0.84 & 5.294 & 0.209 & 0.215 \\
\hline \multirow{2}{*}{ 6 luni } & Sep lin & 1.694 & 0.72 & 2.828 & 0.18 & 0.204 \\
\cline { 2 - 7 } & Control & 1.883 & 0.84 & 4.504 & 0.208 & 0.215 \\
\hline
\end{tabular}
(5).

Septilin determină scăderea GI, GBI şi TNF $\alpha$

Rezultatele unui studiu clinic au arătat rolul lui Septilin în tratarea pacienților cu parodontită cronică. Aceştia au prezentat o îmbunătătire semnificativă a parametrilor clinici GI şi GBI, dar şi o scădere a $\mathrm{TNF} \alpha$.

Tuturor pacienților incluşi în acest studiu le-a fost realizat iniţial detartraj şi planare radiculară. Apoi au fost împărțiţi în două grupuri: grup control şi un grup care a primit tratament cu Septilin, 2 tablete, de două ori pe zi, timp de 2 săptămâni. Pacienții au fost evaluați din punct de vedere clinic şi biochimic la începutul studiului, la 2 săptămâni, la 3 şi la 6 luni.

\begin{tabular}{|l|c|c|c|c|}
\hline Perioadă evaluare & Grup & GI & GBI & TNF $\boldsymbol{\alpha}$ \\
\hline Pre-tratament & Sep lin & 1,91 & 0,93 & 6,74 \\
\hline & Control & 2,01 & 0,98 & 2,55 \\
\hline 2 săptămâni & Sep lin & 1,65 & 0,71 & 3,03 \\
\hline & Control & 1,94 & 0,86 & 2,73 \\
\hline 3 luni & Sep lin & 1,56 & 0,68 & 2,86 \\
\hline & Control & 1,9 & 0,84 & 2,79 \\
\hline 6 luni & Sep lin & 1,52 & 0,65 & 2,55 \\
\hline & Control & 1,88 & 0,81 & 2,68 \\
\hline
\end{tabular}




\section{BIBLIOGRAFIE}

1. Shklar G. Ancient India and China. In: Carranza F., Shklar G., editors. History of Periodontology. Chicago, IL: Quintessence Publishing Co. Inc., 2003: 9-11.

2. Kroes I., Lepp P.W., Relman D.A. Bacterial diversity within the human subgingival crevice. Proc Natl Acad Sci USA 1999:96:14547-14552.

3. Marsh P.D. Contemporary perspective on plaque control 2012, Br Dent J. 2012 Jun 22; 212(12):601-6. doi: 10.1038/ sj.bdj.2012.524.

4. Shetty S., Bose A., Thoudam B. A Comparative Evaluation of Clinical Efficacy and Salivary and Gingival Crevicular Fluid
Interleukin - 6 Levels with Herbal and Probiotic Host Modulation Therapy in Chronic Periodontal Disease, International Journal of Dentistry and Oral Health, 1(2):ISSN 2378-7090, May 2015.

5. Shetty S., Bose A., Sridharan S., Satyanarayana A., Rahul A. "A Clinico-Biochemical Evaluation of the Role of a Herbal (Ayurvedic) Immunomodulator in Chronic Periodontal Disease: A Pilot Study", Oral health and dental management, Vol. 12 - No.2, 95-104, June 2013. 